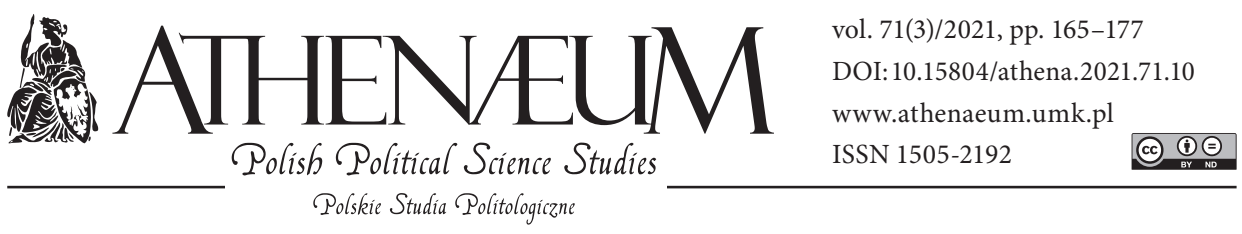

\title{
COOPERATION BETWEEN POLAND AND THE UNITED STATES WITHIN THE THREE SEAS INITIATIVE
}

\author{
WSPÓŁPRACA POLSKI I STANÓW ZJEDNOCZONYCH \\ W RAMACH INICJATYWY TRÓJMORZA
}

Łukasz Jureńczyk* (1)

\begin{abstract}
Celem artykułu jest analiza i ocena współpracy między Polską i Stanami Zjednoczonymi w zakresie wdrażania w życie Inicjatywy Trójmorza. We wprowadzeniu zarysowano specyfikę i cele TSI oraz główne założenia metodologiczne artykułu. Dwie pierwsze części poświęcono odpowiednio geopolitycznemu i gospodarczemu znaczeniu TSI dla Polski oraz dla regionu Europy ŚrodkowoWschodniej i USA. Zasadnicza część artykułu koncentruje się na wspólnych działaniach Polski i Stanów Zjednoczonych na rzecz promowania i wdrażania TSI.

Problem badawczy zawiera się w dwóch pytaniach badawczych: Czy zainicjowanie przez Polskę TSI zwiększyło jej znaczenie w polityce zagranicznej i bezpieczeństwa USA? Czy Polsce skutecznie udało się włączyć USA do współpracy na rzecz rozwoju TSI? Dzięki inicjatywie Polska umocniła w USA wizerunek lidera regionu, a administracja Donalda Trumpa zdecydowanie poparła i zaangażowała się w projekt. Istnieją
\end{abstract}

The aim of the paper is to analyze and evaluate the cooperation between Poland and the United States in the implementation of the Three Seas Initiative. The introduction outlines the specificity and objectives of the TSI as well as the main methodological assumptions of the paper. The first two sections are devoted to the geopolitical and economic significance of the TSI for Poland, as well as Central and Eastern Europe and the TSI for the US, respectively. The main section of the paper focuses on the joint activities of Poland and the United States to promote and implement the TSI.

The research problem is contained in two research questions: Has the initiation of the TSI by Poland increased its importance in the US foreign and security policy? Has Poland successfully involved the US in cooperation for the development of the TSI? Thanks to the initiative, Poland strengthened the image of the region's leader in the US, and the Donald Trump administration

* Kazimierz Wielki University in Bydgoszcz, Faculty of Political Sciences and Public Administration. 
szanse dalszej współpracy w ramach TSI, ponieważ podejście administracji Joego Bidena do tego projektu jak dotąd jest pozytywne. Podczas badań skorzystano z metody analizy źródeł tekstowych.

Słowa kluczowe: Inicjatywa Trójmorza; współpraca polsko-amerykańska; geopolityka; bezpieczeństwo energetyczne strongly supported and committed to the project. There are opportunities for further cooperation under TSI as the approach of the Joe Biden administration to this project has been positive so far. During the research, the method of analyzing text sources was used.

Keywords: the Three Seas Initiative (TSI); Polish-American cooperation; geopolitics; energy security

\section{INTRODUCTION: THE THREE SEAS INITIATIVE}

The idea of establishing a new platform for regional cooperation was put forward in 2015 by the presidents of Poland and Croatia - Andrzej Duda and Kolinda Grabar-Kitarović. The Three Seas Initiative (TSI) was formally established at its first summit on August 25, 2016 in Dubrovnik, Croatia. It brings together twelve countries located between the Baltic Sea, the Adriatic Sea, and the Black Sea, i.e., Austria, Bulgaria, Croatia, the Czech Republic, Estonia, Hungary, Latvia, Lithuania, Poland, Romania, Slovakia, and Slovenia. These countries share a common geographic, and to a large extent also historical and political identity (Lewkowicz, 2019). The twelve TSI countries cover about $30 \%$ of the territory of the European Union, they are home to about $25 \%$ of its population and, according to purchasing power parity, they generate about $20 \%$ of GDP.

The declared pillars and objectives of the TSI are: boosting economic development; strengthening the cohesion of the European Union; and enriching the transatlantic ties (Joint Declaration of the Third Summit..., 2018). In practice, this international forum is primarily a tool for the development of cross-border transport, energy and telecommunications infrastructure (Jančošekovà, 2017). The transport projects include the 'Via Carpatia' highway from Klaipeda in Lithuania to Thessaloniki in Greece, the 'Via Baltica' and the 'Rail Baltica' from Warsaw to Tallinn in Estonia, and a number of other road, rail and inland waterway links. In terms of energy infrastructure, it includes LNG terminals in Świnoujście in Poland and on the island of Krk in Croatia, as well as a number of gas and oil pipelines, interconnectors, and storage facilities. In the telecommunications dimension, an important role plays the development of modern information technologies, including the fifth generation mobile network (5G). However, 
observers ascribe to the initiative also long-term goals of a political nature, aimed at changing the balance of power in Europe. Through internal integration, Central and Eastern Europe (CEE) would cease to be a peripheral area of the EU. The implementation of economic goals could lead to closer political and military cooperation within the 'spill-over' effect known from the theory of European integration (Kowal \& Orzelska-Stączek, 2019).

Every year, the TSI summits are held, which have so far taken place in Dubrovnik (2016), Warsaw (2017), Bucharest (2018), Ljubljana (2019), and Tallinn (2020). During the summits, cooperation mechanisms were established, including: TSI Investment Fund; the network of chambers of industry and commerce of the TSI countries; the Business Council of the TSI; and the creation of a joint index of TSI countries' stock exchanges - CEEplus - was announced.

The paper is devoted to the issue of cooperation between Poland and the United States in the implementation of the Three Seas Initiative, and its aim includes the analysis and evaluation of this cooperation. The main research questions are: Has the initiation of the TSI by Poland increased its importance in the US foreign and security policy? Has Poland successfully involved the US in cooperation for the development of the TSI? The answers to the questions were provided through the use of the method of analysis of text sources, including the examination of the content of agreements, declarations and statements. The initiation and promotion of the project by Poland strengthened its image as a regional leader in the United States. The Donald Trump administration strongly supported and committed to the implementation of the TSI as it was in its interests.

\section{GEOPOLITICAL AND ECONOMIC IMPORTANCE OF THE THREE SEAS INITIATIVE FOR POLAND}

To some extent, the Three Seas Initiative is a reactivation of the interwar geopolitical concept of the Intermarium, which is a reference to the Jagiellonian traditions of Poland. Within its framework, Poland's foreign policy was to be aimed at building the state's international position as a regional leader and superpower. The Polish authorities are renouncing the TSI's direct relationship with the Intermarium concept, not least because it had negative consequences for Czechoslovakia and Lithuania (Varga \& Buzogány, 2020). For Poland, TSI is primarily a platform for cooperation to overcome communist-era legacies and 
'catch up' to the Western Europe economically (Soroka \& Stępniewski, 2019). The Polish authorities emphasize that this is mainly an economic and commercial project, not a political one. They ensure that TSI is not meant to be an alternative to European integration. It is intended to be a regional cooperation that benefits all participants and is implemented within the EU (Szułdrzyński, 2016).

The arguments of the Polish authorities are not fully accepted in Western Europe, including by Germany, which is dominant in the European Union. Especially at the beginning it was perceived as an attempt to change the balance of power in Europe. The regional bloc of states, under the umbrella of the United States, was to build a counterbalance to the so-called 'Old Europe', and above all, the German-French tandem dominating in the EU (Lewkowicz, 2019). This perception was influenced by the illiberal trend in the policy of the Law and Justice party, the conflict with European institutions, as well as the distrust and reluctance of the Polish authorities towards Western European political elites. Poland emphasizes, however, that the TSI is a pro-integration project in Europe, which only aims to level the playing field between the EU members. The Polish authorities refute allegations that their aim is to weaken the position of Germany and France in favor of the United States. However, this does not change the fact that Poland is committed to deepening its relations with the US and embedding its political, economic and military interests in Europe, especially in its central and eastern parts.

For Poland, the TSI is of particular importance in the context of relations with Russia. The Polish authorities want to strengthen CEE so that it can effectively resist pressure from the eastern superpower. First of all, it concerns energy security, including the blackmail used by Gazprom against the countries of the region. The implementation of the project makes it possible for the CEE countries to become independent of Russian supplies of energy resources (Soroka \& Stępniewski, 2019). Poland wants to become a regional hub for natural gas imported from the United States. Even though the TSI countries have adopted different directions for the development of their own energy sectors (Anghel, 2020), most of them share the concerns about Russia's energy policy. However, there are those, including Hungary, Slovakia, and Austria, who want to maintain close energy cooperation with Russia.

Poland also proposes political cooperation and building a community of interests in the area of other security aspects, including military, among TSI countries (Sienkiewicz, 2016). This mainly concerns the north-east and southeast directions (Szułdrzyński, 2016). In November 2015, in Bucharest, Poland and 
Romania organized a summit of the states of NATO's eastern flank, initiating the cooperation formula of the so-called Bucharest Nine (B9). It is a regular meeting of defense ministers of the Visegrad Group countries (the Czech Republic, Hungary, Poland, and Slovakia), the Baltic states (Estonia, Lithuania, and Latvia), Bulgaria and Romania. The goal of B9 is to jointly lobby the interests of the states of the Alliance's eastern flank in the context of the threat from Russia. The B9's proposals were adopted at the NATO summit in Warsaw in July 2016, including: the Enhanced Forward Presence (EFP); updating contingency plans; definition of cyberwarfare; and intensification of military exercises in CEE (Larsen, 2017). It is worth mentioning that Poland offered the United States over \$2 billion for locating the American division on its territory under the 'Fort Trump' concept. A permanent US force base in Poland would certainly strengthen its position in Europe, but for many reasons this postulate was not implemented by the ally.

\section{GEOPOLITICAL AND ECONOMIC IMPORTANCE OF CENTRAL AND EASTERN EUROPE AND THE THREE SEAS INITIATIVE FOR THE UNITED STATES}

In the declining stage of the Cold War, Soviet-dominated Central and Eastern Europe played an important role in US foreign and security policy. The interest persisted at the turn of the century, as the countries in the region received American support in the process of political transformation. In the twenty-first century, the administration of George W. Bush tightened cooperation with the region, effectively gaining its support in the global war on terror. It was only during the first term of President Barack Obama that the importance of CEE, and thus American influence in the region, decreased (Inbar \& Rynhold, 2016). It was caused by the policy of 'reset' of relations with Russia and the strategic shift towards Asia ('pivot to Asia') (Renshon, 2010). However, due to the crisis in Ukraine, the Obama administration took a number of steps to strengthen the military security of CEE countries.

For President Trump, involvement in Central and Eastern Europe, as well as support for the Three Seas Initiative, were primarily motivated by business factors. As most of the countries in the region are relatively underdeveloped, this creates great investment and trade opportunities for the United States. President Trump's disputes with the leaders of Western European countries, including Germany and France, favored the tightening of relations with CEE. 
He collaborated much more willingly with Poland, perceived as the leader of TSI, whose authorities of Law and Justice were much closer to him ideologically. Strategic issues, such as competition in the CEE with other superpowers, were also of significant importance to him. For the above reasons, the TSI has become a forum for the US to promote economic and political interests in the region.

Ian Brzeziński from the Atlantic Council stated that the Three Seas Initiative brings real value to the transatlantic community by increasing Europe's economic strength. According to him, the TSI should receive clear and systematic support from the US and the EU. His associate, Benjamin Haddad, said that the reconfiguration of global supply chains in the post-pandemic world would create huge opportunities for the Three Seas region. The European Union, strengthened by the TSI, would be a more serious partner for the US in the competition with China and Russia (Polski Instytut Ekonomiczny, 2020). Problematic, however, was President Trump's reluctance to the European Union, its institutions and neo-liberal elites.

The United States is cooperating with the CEE countries to overcome Russia's raw material monopoly and to increase their energy security. Based on this cooperation, the Trump administration wanted to make the US an LNG export powerhouse. Europe's share of American LNG exports was expected to increase from from 13.1\% in 2019 to $60 \%$ in 2035 (Chojan, 2019). The North-South gas corridor built under the TSI was supposed to enable the sale of American LNG to all countries in the region. Moreover, the TSI was potentially a sales platform for their renewable energy and civil nuclear energy technologies.

For the United States, CEE is one of the areas of strategic competition with China. The superpowers want to attract the countries of the region to cooperation and thus shape the principles of globalization that favor their economic and political interests (Lewicki, 2020). China cooperates with CEE countries within the ' $17+1$ ' concept. Its aim is to deepen infrastructure, communication, investment and commercial cooperation. Beijing promotes a global strategy for infrastructure development - the Belt and Road Initiative (BRI), which in CEE would be coupled with the TSI. The United States, in turn, is tightening its cooperation with the TSI countries to inhibit the development of Chinese influence in the region (Chojan, 2019). While some elements of the rivalry in CEE between the US and China may be collision-free, there are also those that directly lead to a conflict. Currently, 5G technology is an important area of competition.

For the US, CEE is also important from a political and military point of view, and the TSI may potentially constitute an additional platform for strengthening 
military ties, mainly with the countries of NATO's eastern flank. The United States is increasing its military presence in the region. At the same time, they are putting pressure on the countries of the 'Old Europe', mainly Germany, to assume greater responsibility for defending the continent. Criticism of RussianGerman energy projects and the positive example of some TSI countries, including Poland, in terms of financing the army, were important arguments for the administration of President Trump in this action. An effective attack by Russia on the NATO's eastern flank country would undermine the credibility of the American security guarantees for Europe and lead to a redefinition of the role and status of the superpower in the world (Terlikowski, 2020). From the perspective of the American administration, the strategic significance of the TSI increased even more as a consequence of the electoral crisis in Belarus that began in August 2020. Secretary of State Mike Pompeo stated that the TSI has become even more important in terms of Russia and China's policy in the region (Obremski, 2020).

\section{JOINT ACTIONS OF POLAND AND THE UNITED STATES FOR THE IMPLEMENTATION OF THE THREE SEAS INITIATIVE}

President Andrzej Duda and the government of Prime Minister Beata Szydło made decisive efforts to involve Donald Trump's administration in the implementation of the Three Seas Initiative. Thanks to these efforts, President Trump participated in the second TSI summit in Warsaw on July 6, 2017, which significantly increased the international rank of the meeting. The American president supported the initiative, pointing to its potential for the development of cross-border infrastructure and strengthening the energy security of Central and Eastern European countries. Moreover, he emphasized the possibility of tightening investment and trade cooperation with US enterprises and the transfer of American technologies (U.S. Government Information, 2017). The representatives of the United States also took part in the following Three Seas summits as observers.

President Trump sent a letter to the participants of the third Three Seas Summit in Bucharest on September 17-18, 2018, confirming the full American support for the project. He assured the US administration's involvement in the development of the region's infrastructure, strengthening energy security, deepening business cooperation and lifting trade restrictions (A Letter from..., 2018, 
as cited in: Chojan, 2019). Participating in the summit Secretary of Energy Rick Perry presented the Partnership for Transatlantic Energy Cooperation initiative (P-TEC), which aims to develop US energy cooperation with the TSI countries. Successive P-TEC summits formulate and implement action plans in this area. In the meantime, representatives of the Polish authorities held a series of meetings in the US with representatives of American enterprises, mainly from the energy, telecommunications and construction sectors, convincing them to invest in Poland and ECC (Wilczek, 2020).

Presidents Duda and Trump referred to the Three Seas Initiative in the strategic partnership declaration signed in Washington on September 18, 2018. In the section devoted to trade, investments, research and innovations, they declared to work in these fields "aggressively to fill the untapped potential, including through the Three Seas Initiative" to contribute to the implementation of economic priorities of ECC countries (Safeguarding Freedom..., 2018). The signatories of the document emphasized the importance of cooperation within the TSI, mainly in the area of broadly understood infrastructure, including energy and transport (The White House, 2018).

So far, the main area of the Polish-American cooperation within the TSI has been energy. For the United States, the goal of cooperation is to create a common gas market in the CEE region, open to supplies of American LNG (Wiech,2020). On November 8, 2018, in Warsaw, Minister of Energy Krzysztof Tchórzewski and Secretary Perry signed a Joint Declaration Concerning Enhanced Cooperation on Energy Security. They declared the development of cooperation aimed at increasing diversification and ensuring the stability of supplies of energy sources. This is to increase the energy security of Poland and CEE, especially in the face of pressure from Russian state-owned energy companies. The parties agreed to promote cooperation not only in the field of hydrocarbons, but also in nuclear and renewable energy (Joint Declaration between..., 2018).

In 2017-2018, Polish Oil Mining and Gas Extraction (PGNiG) signed longterm (about 25-year) contracts with the American companies - Port Arthur LNG, Venture Global LNG, and Cheniere Energy for the purchase of natural gas from the US. Their volume covers about one third of today's Polish demand for LNG. Imports are to fill the gap that will appear in 2022 due to the expiry of the Yamal contract for the import of Russian gas. Both Poland and the US want the imported American LNG to be shipped to other countries of CEE. This is to be made possible by the expansion of gas terminals and transmission networks under the TSI (The White House, 2018). 
Like the Polish authorities, President Trump began to strongly criticize the construction of the Nord Stream II (NS II) gas pipeline, which is to connect Germany and Russia via the Baltic Sea. He regarded this project as a political undertaking that threatens Europe's energy security (The White House, 2019). In the US, legal tools have been established to impose sanctions on companies participating in the project, including the Countering America's Adversaries Through Sanctions Act (CAATSA) of August 2017 and the National Defense Authorization Act (NDAA) of December 2020. US sanctions slowed down and called into question the finalization of NS II. In the meantime, the United States supported the implementation of a number of energy projects contributing to the increase in energy security of the TSI countries, including the construction of the Baltic Pipe from Norway to Poland, the expansion of the LNG terminal in Świnoujście, the construction of the LNG terminal in Gdańsk, and the construction of the interconnector between Bulgaria, Romania, Hungary, and Austria (Joint Declaration between..., 2018).

During the Munich Security Conference in February 2020, Secretary Pompeo declared that the US would contribute $\$ 1$ billion to the Three Seas Fund. Money were to be transferred by the American government agency - International Development Finance Corporation (DFC). This was to revive private investments in the energy sectors of the TSI countries, with priority being given to the development and modernization of energy infrastructure, including energy sources transmission lines (Wilczek, 2020). At the fifth TSI summit in Tallinn on October 19-20,2020, the US delegation announced the transfer by DFC of the first tranche of $\$ 300$ million, which was approved in December (Tallinn Summit..., 2020). At the end of Donald Trump's administration, on November 18,2020 , the U.S. House of Representatives unanimously passed a resolution expressing support for the TSI. The resolution includes 43 bipartisan cosponsors, which shows a political consensus on this issue.

According to President Duda, the Three Seas Initiative was to attract American investors to Poland and the region also from other industries. Investment declarations have actually started to appear. For example, Microsoft announced $\$ 1$ billion to build a modern data center in Poland. In turn, Google announced the construction of a modern technology center in Poland, including information technology (The White House, 2020). The interest of the ICT industries was fostered by Poland's declaration of abandoning Chinese 5G technology. Moreover, the Polish authorities have refrained from imposing a digital tax on American ICT companies (Lenik, 2020). 
The administration of Joe Biden has confirmed its readiness to support the energy security of TSI countries, including through the P-TEC (Nowak, 2021). Nevertheless, President Biden's administration withdrew from sanctions against entities building Nord Stream 2, which was received with great concern by the Polish authorities. On the other hand, the issue of preventing negative climate change, which was neglected by the Donald Trump administration, is of key importance in the domestic and international politics of the new American administration. One of President Biden's first decisions was to return to the Paris Agreement. The Three Seas Initiative countries can become important US partners in promoting global reductions in greenhouse gas emissions. This is due to the fact that the region is the largest polluter in Europe, therefore it must take far-reaching measures to meet EU environmental requirements. In doing so, the TSI states can benefit from significant EU aid funds for the transformation of their energy systems. Cooperation within the TSI and US support can significantly accelerate transformation programs. These activities should also contribute to strengthening energy cooperation within the EU, as Western European countries focus on clean energy.

\section{CONCLUSION}

Both for Poland and the United States, the Three Seas Initiative is of significant geopolitical and economic importance. Poland sees it primarily as an opportunity to level the development opportunities in Europe and to strengthen the energy security of Central and Eastern Europe. The United States, in turn, sees it as a great investment and trade opportunity, as well as a way to strengthen its position in the region in the context of competition with other superpowers.

The TSI states do not have the ability to geopolitically balance two centers of power in Europe, i.e., Russia and Western Europe. This is due to both their limited potential and their diversified interests (Zięba, 2018). Undoubtedly, the strong support of the initiative from the administration of President Donald Trump strengthened this potential. The coherence of interests and the ideological closeness of the Polish and American authorities were conducive to the US involvement in the TSI. Polish-American energy cooperation under the TSI was beneficial for both the US and CEE. The joint actions primarily led to a reduction in energy dependence on Russia. Thus, in the eyes of the Donald Trump administration, Poland has strengthened its position as the region's leader. The 
tightening of cooperation under the TSI was accompanied by an increase in the US military presence in Poland, but on a much smaller scale than expected by the Polish authorities.

In the US Congress, the Three Seas Initiative has cross-party support and President Joe Biden's administration remains positive about the initiative. As the new American administration wants to make the US a world leader in green energy technologies, the TSI offers opportunities to tighten cooperation in this area. On the other hand, the first tensions appear in connection with Poland's failure to respect the principles of the rule of law and democracy. Maintaining close cooperation between Poland and the US, including in the field of the TSI development, will largely depend on the internal policy of the Polish authorities. It should also be expected that the current US administration will focus on CEE to a lesser extent than the previous one. It will also try to rebuild close relations with the powers of Western Europe, including Germany, leaving them with greater independence in European policy matters, including the CEE and the TSI.

\section{REFERENCES:}

A Letter from the President of the United States Donald Trump to the Participants of the Business Forum Organized on the Occasion of the Three Seas Summit in Bucharest in September 2018 (2018). Washington D.C.

Anghel, V. (2020). Together or Apart? The European Union's East-West Divide. Survival: Global Politics and Strategy, 62(3), 179-202. DOI: 10.1080/00396338.2020.1763621. Chojan, A. (2019). The United States on the Three Seas Initiative. Yearbook of the Institute of East-Central Europe, 17(3), 79-91. DOI: 10.36874/RIESW.2019.3.5.

Inbar, E., \& Rynhold, J. (2016). Introduction. In: E. Inbar, \& J. Rynhold (Eds.). US Foreign Policy and Global Standing in the 21 $1^{\text {st }}$ Century: Realities and Perceptions (pp. 1-12). London-New York: Routledge.

Jančošekovà, V. (2017). Regional Cooperation in Central and Eastern Europe and Its Implications for the EU. European View, 16(2), 231-238. DOI: 10.1007/s12290017-0460-8.

Joint Declaration between the United States Department of Energy and the Ministry of Energy of the Republic of Poland Concerning Enhanced Cooperation on Energy Security (2018 November 8). Gov.pl. Retrieved from: https://www.gov.pl/web/ aktywa-panstwowe/wzmocnienie-polsko-amerykanskiej-wspolpracy-w-zakresiebezpieczenstwa-energetycznego.

Joint Declaration of the Third Summit of the Three Seas Initiative (2018, September 17-18). Bucharest. Three Seas Initiative. Retrieved from: http://three-seas.eu/wpcontent/uploads/2018/09/BUCHAREST-SUMMIT-JOINT-DECLARATION.pdf. 
Kowal, P., \& Orzelska-Stączek, A. (2019). Inicjatywa Trójmorza. Geneza, cele i funkcjonowanie. Warszawa: Instytut Studiów Politycznych PAN.

Larsen, J.A. (2017). NATO's Responses to Russian Belligerence: An Overview. In: K. Friis (Ed.). NATO and Collective Defence in the 21 $1^{\text {st }}$ Century: An Assessment of the Warsaw Summit (pp. 8-15). London-New York: Routledge.

Lenik, D. (2020, January 29). “Złoty rok” w relacjach polsko-amerykańskich? - co wydarzyło się w 2019 roku. Instytut Nowej Europy. Retrieved from: http://ine.org. pl/zloty-rok-w-relacjach-polsko-amerykanskich-co-wydarzylo-sie-w-2019-roku/.

Lewicki, G. (2020). China's Belt and Road Meets the Three Seas Initiative: Chinese and US Sticky Power in the Context of the COVID-19 Pandemic and Poland's Strategic Interests. Warsaw: Polish Economic Institute. Retrieved from: https://pie.net.pl/ wp-content/uploads/2018/07/PIE_Belt-and-Road.pdf.

Lewkowicz, Ł. (2019). The Three Seas Initiative in the Context of International Challenges. Yearbook of the Institute of East-Central Europe, 17(3), 7-12. DOI: 10.36874/ RIESW.2019.3.1.

Nowak, Z. (2021, January). Greening the Three Seas Initiative with the U.S. PISM Policy Paper, 4. Warszawa: Polski Instytut Spraw Międzynarodowych.

Obremski, M. (2020, September 15). USA: Pompeo: w świetle wydarzeń na Białorusi wsparcie Trójmorza jeszcze ważniejsze. Dziennik Gazeta Prawna. Retrieved from: https://www.gazetaprawna.pl/artykuly/1490987,usa-pompeo-w-swietle-wydarzenna-bialorusi-wsparcie-trojmorza-jeszcze-wazniejsze.html.

Polski Instytut Ekonomiczny (2020, June 17). Trójmorze jako obiekt sporu Chin i Stanów Zjednoczonych. Retrieved from: https://pie.net.pl/trojmorze-jako-obiekt-sporuchin-i-stanow-zjednoczonych/.

Renshon, S.A. (2010). National Security in the Obama Administration: Reassessing the Bush Doctrine. London-New York: Routledge.

Safeguarding Freedom, Building Prosperity through Poland-US Strategic Partnership (2018, September 19). BBN. Retrieved from: https://en.bbn.gov.pl/en/ news/670,Safeguarding-freedom-building-prosperity-through-Poland-USStrategic-Partnership.html.

Sienkiewicz, M. (2016). Koncepcja Trójmorza w polityce zagranicznej Polski po 2015 r. Dyplomacja i bezpieczeństwo, 1, 139-151.

Soroka, G., \& Stępniewski, T. (2019). The Three Seas Initiative: Geopolitical Determinants and Polish Interests. Yearbook of the Institute of East-Central Europe, 17(3), 15-29. DOI: 10.36874/RIESW.2019.3.2.

Szułdrzyński, M. (2016, September 8). Krzysztof Szczerski: Trójmorze nie jest alternatywą dla UE. Rzeczpospolita. Retrieved from: https://www.rp.pl/Rzecz-opolityce/160909481-Krzysztof-Szczerski-Trojmorze-nie-jest-alternatywa-dla-UE. html.

Tallinn Summit Marks Significant Progress in Three Seas Initiative (2020, October 19). Atlantic Council. Retrieved from: https://www.atlanticcouncil.org/news/pressreleases/tallinn-summit-marks-significant-progress-in-three-seas-initiative/. 
Terlikowski, M. (2020). Sojusz Północnoatlantycki w polityce administracji Donalda Trumpa. Początek rozstania czy wielki powrót? In: W. Paruch, M. Pietraś, \& B. Surmacz (Eds.). Sojusz Pólnocnoatlantycki w środowisku niepewności i zmiany. Dwadzieścia lat członkostwa Polski (pp. 160-176). Warszawa: Wydawnictwo Sejmowe.

The White House (2018, September 18). Remarks by President Trump and President Duda of the Republic of Poland in Joint Press Conference. Washington D.C. Retrieved from: https://trumpwhitehouse.archives.gov/briefings-statements/remarkspresident-trump-president-duda-republic-poland-joint-press-conference/.

The White House (2019, June 12). Remarks by President Trump and President Duda of the Republic of Poland in Joint Press Conference. Washington D.C. Retrieved from: https://www.whitehouse.gov/briefings-statements/remarks-president-trumppresident-duda-republic-poland-joint-press-conference-2/.

The White House (2020, June 24). Remarks by President Trump and President Duda of the Republic of Poland in Joint Press Conference. Washington D.C. Retrieved from: https://www.whitehouse.gov/briefings-statements/remarks-president-trumppresident-duda-republic-poland-joint-press-conference-3/.

U.S. Government Information (2017, July 6). Remarks at the Three Seas Initiative Summit in Warsaw, Poland. Retrieved from: https://www.govinfo.gov/content/pkg/ DCPD-201700452/html/DCPD-201700452.htm.

Varga, M., \& Buzogány, A. (2020). The Foreign Policy of Populists in Power: Contesting Liberalism in Poland and Hungary. Geopolitics, 25, 1-22. DOI: $10.1080 / 14650045.2020 .1734564$.

Wiech, J. (2020, March 25). Gazem i atomem. USA i Rosja walczą o geopolityczne wpływy, Polska polem bitwy. Analiza. Energetyka24. Retrieved from: https://www. energetyka24.com/gazem-i-atomem-usa-i-rosja-walcza-o-geopolityczne-wplywypolska-polem-bitwy-analiza.

Wilczek, P. (2020, June 15). Współpraca polsko-amerykańska w latach 2016-2020. Fakty i liczby. Warsaw Institute. Retrieved from: https://warsawinstitute.review/pl/ aktualnosci/wspolpraca-polsko-amerykanska-w-latach-2016-2020/.

Zięba, R. (2018). Polityka bezpieczeństwa Polski. In: R. Zięba (Ed.). Bezpieczeństwo międzynarodowe w XXI wieku (pp. 445-472). Warszawa: Wydawnictwo Poltext. 